\title{
Suppressive Effects of Polysaccharide Produced by Bacillus circulans on Chemical Mutagens-Induced SOS Response in Salmonella typhimurium
}

\author{
Yuka Isobe, Kumio Yokolgawa and Hiroyasu KaWAI \\ Department of Food Science and Nutrition, Nara Women's University, Nara 630, Japan
}

Received August 4, 1997; Accepted November 14, 1997

\begin{abstract}
The suppressing effects of polysaccharide produced by Bacillus circulans on the SOS response of Salmonella typhimurium TA 1535/pSK1002 induced by AF-2, MNNG, 4NQO, Trp-P-2, IQ and MeIQx were compared with those of commercial polysaccharides to find a new physiological value as an additive to processed foodstuffs. The native polysaccharide produced by $B$. circulans strongly suppressed SOS response induced by IQ and MeIQx, and the suppression was increased with increasing polysaccharide concentration. Xanthan gum, which is an acidic polysaccharide produced by Xanthomonas campestris, and carboxymethyl cellulose (CMC) did not suppress SOS response induced by mutagens.
\end{abstract}

Keywords: SOS response, polysaccharide, Bacillus circulans

Some physiological functions of food, in addition to its taste and nutritional functions, have been attracted attention in recent year. It has been reported that many kinds of vegetables, fruits and cereals have antimutagenicity (Morita $e t$ al., 1978; Edenharder et al., 1995), and that their fibers, high-molecule substances, have anticarcinogenicity by adsorbing carcinogens from various sources (Burkitt, 1971; Barbolt \& Abraham, 1978; Barnes et al., 1983; Kada et al., 1984; Takeuchi et al., 1988; Hayatsu et al., 1988). Okabe et al. (1996) have reported that a water-soluble fraction and a viscous fraction isolated from root crops had a suppressing effect on Trp-P-2-induced mutagenicity.

We have isolated a highly viscous exopolysaccharide from a culture medium of a soil bacterium, Bacillus circulans, when it was grown on a medium containing glucose as a carbon source. We investigated the culture conditions of the bacterium for the production of polysaccharide (Kawai et al., 1992), and the physicochemical properties of the bacterial polysaccharide (BPS) were examined to apply it to the food industry as raw materials (Isobe et al., 1996).

In this paper, we report the suppressing effects of BPS produced by $B$. circulans on the SOS response of Salmonella typhimurium induced by chemical mutagens by measuring the $\beta$-galactosidase activity of the bacteria corresponding to the $u m u \mathrm{C}$ gene expression against DNA damage.

\section{Materials and Methods}

Chemicals $\quad N$-Methyl- $N^{\prime}$-nitro- $N$-nitrosoguanidine (MNNG) was purchased from Aldrich Chemical Co., (Milwaukee, Wis.) and other mutagens were obtained from Wako Pure Chemical Industries (Osaka). An S9 mix was obtained from Oriental Yeast Industries (Tokyo). The other chemicals were analytical grade reagents from Nacalai Tesque, Inc., Kyoto and Wako Pure Chemical Industries.

Culture conditions of bacteria for polysaccharide production A culture medium of $B$. circulans for polysac- charide production contained $1 \%$ glucose, $0.05 \%$ asparagine, $0.005 \%$ yeast extract, $0.05 \% \mathrm{KH}_{2} \mathrm{PO}_{4}, 0.005 \% \mathrm{MgSO}_{4} \cdot 7 \mathrm{H}_{2} \mathrm{O}$, $0.005 \% \mathrm{CaCl}_{2} \cdot 2 \mathrm{H}_{2} \mathrm{O}$ and $0.005 \% \mathrm{FeCl}_{3} \cdot 6 \mathrm{H}_{2} \mathrm{O}$. The $\mathrm{pH}$ of the medium was adjusted to 7.0 before autoclaving at $120^{\circ} \mathrm{C}$ for 15 min. A jar-fermentor (MSJ-30, Marubishi B.E. Co., Ltd., Tokyo) culture was performed at $30^{\circ} \mathrm{C}$ for $48 \mathrm{~h}$ with $10 \mathrm{l}$ of the medium by inoculating $1 l$ of a preculture, which was cultured as described in the previous paper (Kawai et al., 1992), with an aeration rate at $1.5 l$ per minute and an agitation speed at $300 \mathrm{rpm}$.

Isolation and purification of polysaccharide Isolation and purification of BPS from the culture broth were performed by the following method: $\mathrm{NaCl}$ was added and dissolved in a culture fluid from a jar-fermentor at a final concentration of $10 \%$, and ethanol was added until no more precipitate of the polysaccharide occurred. The precipitate was collected by filtration and dissolved in distilled water by stirring. The solution was centrifuged at $15,000 \times g$ for $1 \mathrm{~h}$ to remove bacterial cells, and the supernatant fluid was dialyzed overnight against distilled water at $4^{\circ} \mathrm{C}$. The dialyzed solution was lyophilized, and the lyophilized preparation was used for the examinations as a purified polysaccharide.

Preparation of low-molecule polysaccharide Purified polysaccharide $(150 \mathrm{mg}$ ) was dissolved in $150 \mathrm{ml}$ of water, and an appropriate amount of Dowex $50\left(\mathrm{H}^{+}\right.$form $)$was added and stirred for $1 \mathrm{~h}$ to remove cations. The acidic polysaccharide solution obtained was then heated at $100^{\circ} \mathrm{C}$ for $30 \mathrm{~min}$, neutralized by $1 \mathrm{~N} \mathrm{NaOH}$ and lyophilized. The molecular weight of the native polysaccharide was greater than $2,000,000$, and that of the low-molecule polysaccharide was about $100,000-200,000$ when they were determined by HPLC at $40^{\circ} \mathrm{C}$ on $\mathrm{OH}$ pak SB-804 HQ column (Shoko Co., Ltd., Tokyo) using $\mathrm{H}_{2} \mathrm{O}$ as an eluent at a flow rate of $0.5 \mathrm{ml} /$ min and using pullulan (M.W.: $2.37 \times 10^{4}, 4.8 \times 10^{4}, 1.0 \times 10^{5}$, $\left.1.86 \times 10^{5}, 3.8 \times 10^{5}, 1.66 \times 10^{6}\right)$ as standard.

Assay of the suppressive SOS response (umu test) 
Suppression of SOS response was measured by a slightly modified umu test (Oda et al., 1985). Salmonella typhimurium TA1535/pSK 1002 was presented by Dr. Yoshimistu Oda, Osaka Prefectural Institute of Public Health, Osaka. An aliquot of $S$. typhimurium was incubated at $37^{\circ} \mathrm{C}$ for $16 \mathrm{~h}$ with LB broth ( $10 \mathrm{~g}$ bactotrypton, $5 \mathrm{~g}$ yeast extract, $5 \mathrm{~g} \mathrm{NaCl}$ and $50 \mathrm{mg}$ ampicillin in $1 l$ water, $\mathrm{pH} 7.0$ ): it was then diluted 50 -fold with TGA medium ( $10 \mathrm{~g}$ bactotrypton, $5 \mathrm{~g} \mathrm{NaCl}, 2 \mathrm{~g}$ glucose and $20 \mu \mathrm{g}$ ampicilin in $1 /$ water) and further incubated to an appropriate bacterial density (absorbance at $600 \mathrm{~nm}: 0.2-0.25$ ). The standard assay mixture for the suppressing effect on the SOS response contained $20 \mu \mathrm{l}$ of direct or indirect mutagens (see below), $0.3 \mathrm{~g}$ of polysaccharide solution and $2.0 \mathrm{ml}$ of bacterial suspension as previously described. For the assay using indirect mutagens $1.7 \mathrm{ml}$ of the cell suspension was mixed with $0.3 \mathrm{ml}$ of the $\mathrm{S} 9$ mix. After incubation at $37^{\circ} \mathrm{C}$ for $2 \mathrm{~h}$, the mixture was diluted with $0.85 \%$ $\mathrm{NaCl}$ solution, and the cells were collected by centrifugation at $3000 \times g$ for $20 \mathrm{~min}$. The precipitate was resuspended in $0.85 \% \mathrm{NaCl}$ solution; then $\beta$-galactosidase activity of the cell suspension was then assayed (A). The control solution containing $0.3 \mathrm{~g}$ of water in place of the polysaccharide solution was also assayed (B). The percentage suppression of the SOS response was calculated using $(1-\mathrm{A} / \mathrm{B}) \times 100$. The $\beta$-galactosidase activity of the bacterial suspension was assayed as follows: Two hundred microliter of bacterial suspension in $0.85 \% \mathrm{NaCl}$ was vigorously mixed with $1.8 \mathrm{ml}$ of Z-buffer $\left(0.06 \mathrm{M} \mathrm{Na}_{2} \mathrm{HPO}_{4} \cdot 12 \mathrm{H}_{2} \mathrm{O}, 0.04 \mathrm{M} \mathrm{NaH}_{2} \mathrm{PO}_{4} \cdot 2 \mathrm{H}_{2} \mathrm{O}, 0.01 \mathrm{M}\right.$ $\mathrm{KCl}, 0.001 \mathrm{M} \mathrm{MgSO}_{4} \cdot 7 \mathrm{H}_{2} \mathrm{O}$ and $0.05 \mathrm{M} \beta$-mercaptoethanol) in the presence of $50 \mu \mathrm{l}$ of $0.1 \%$ sodium dodesyl sulfate and 10 $\mu 1$ of chloroform. The enzyme reaction was initiated by the addition of $0.2 \mathrm{ml}$ of 2-nitrophenyl- $\alpha$-D-galactopyranoside solution $(4 \mathrm{mg} / \mathrm{ml}$ in $0.1 \mathrm{M}$ phosphate buffer, $\mathrm{pH} 7.2)$, incubated at $28^{\circ} \mathrm{C}$ for $20 \mathrm{~min}$ and stopped with $1.0 \mathrm{ml}$ of $1 \mathrm{M}$ $\mathrm{Na}_{2} \mathrm{CO}_{3} . \beta$-Galactosidase activity was calculated as follows (Miller, 1972);

$$
\beta \text {-Galactosidase unit }=1000(\mathrm{C}-1.75 \times \mathrm{D}) / 0.2 \times \mathrm{E}
$$

where $C$ and $D$ represent the absorbance at $420 \mathrm{~nm}$ and 550 $\mathrm{nm}$, respectively, of the enzyme reaction mixture of the $\beta$ galactosidase assay, and $E$ shows the absorbance at $600 \mathrm{~nm}$ of the bacterial suspension grown in the umu test. The experimental results are expressed as the average of two experiments with triplicate assays.

In the $u m u$ test, furylfuramide (AF-2), MNNG, and 4nitroquinoline-1-oxide (4NQO) were used as direct mutagens, and 3-amino-1,4-dimethyl-5N-pyrido (4,3-b) indole (Trp-P2), 2-amino-3-methylimidazo (4,5-f) quinoline (IQ), and 2amino-3,8-dimethylimidazo (4,5-f) quinoline (MeIQx) were used as indirect mutagens activated by the $\mathrm{S} 9 \mathrm{mix}$.

\section{Results and Discussion}

Effect of mutagen concentration on $\beta$-galactosidase activity and bacterial growth The effect of the concentration of direct and indirect mutagens used in this study on $\beta$ galactosidase activity and bacterial growth was investigated. The SOS-induced activities and cell growth in the reaction mixture containing $0,0.01,0.1,1,3 \mu \mathrm{g} / \mathrm{ml}$ mutagens were measured. For example, in the culture added with $4 \mathrm{NQO}$, the enzyme activity was increased with concentrations up to 1 $\mu \mathrm{g} / \mathrm{ml}$, while the growth of the bacteria was gradually decreased with increasing concentration of 4 NQO. In the case of MeIQx, the enzyme activity was increased with concentrations up to $0.1 \mu \mathrm{g} / \mathrm{ml}$, but it was decreased at a concentration greater than $0.1 \mu \mathrm{g} / \mathrm{ml}$, and the bacterial growth was decreased with the concentration. Other mutagens were also investigated for the dose response of $\beta$-galactosidase activity and bacterial growth (data not shown). From these results, the concentration of each mutagen at which $\beta$-galactosidase activity (400-1000 unit) was induced without much inhibition of bacterial growth was used in the umu test. The concentration of each mutagen used in the $u m u$ test is shown in Table 1 .

Table 1. Suppressing effects of polysaccharide on SOS response induced by various mutagens in Salmonella typhimurium TA1535/pSK1002.

\begin{tabular}{lrccc}
\hline Mutagen & \multicolumn{4}{c}{ Suppression (\%) } \\
\cline { 2 - 5 }$(\mu \mathrm{g} / \mathrm{ml})$ & BPS & CMC & Guar gum & Xanthan gum \\
\hline AF-2 (0.03) & 9.0 & 2.3 & 5.4 & 4.2 \\
MNNG (3.0) & 22.8 & 3.8 & 6.6 & 13.7 \\
4NQO (0.3) & 15.2 & 5.7 & 6.8 & 14.9 \\
IQ (0.3) & 73.4 & 1.0 & 55.3 & 6.0 \\
MeIQx (0.03) & 72.5 & 5.4 & 51.6 & 11.8 \\
Trp-P-2 (3.0) & 31.7 & 0.8 & 21.6 & 5.5 \\
\hline
\end{tabular}

Three tenth gram of polysaccharide was used in umu test.

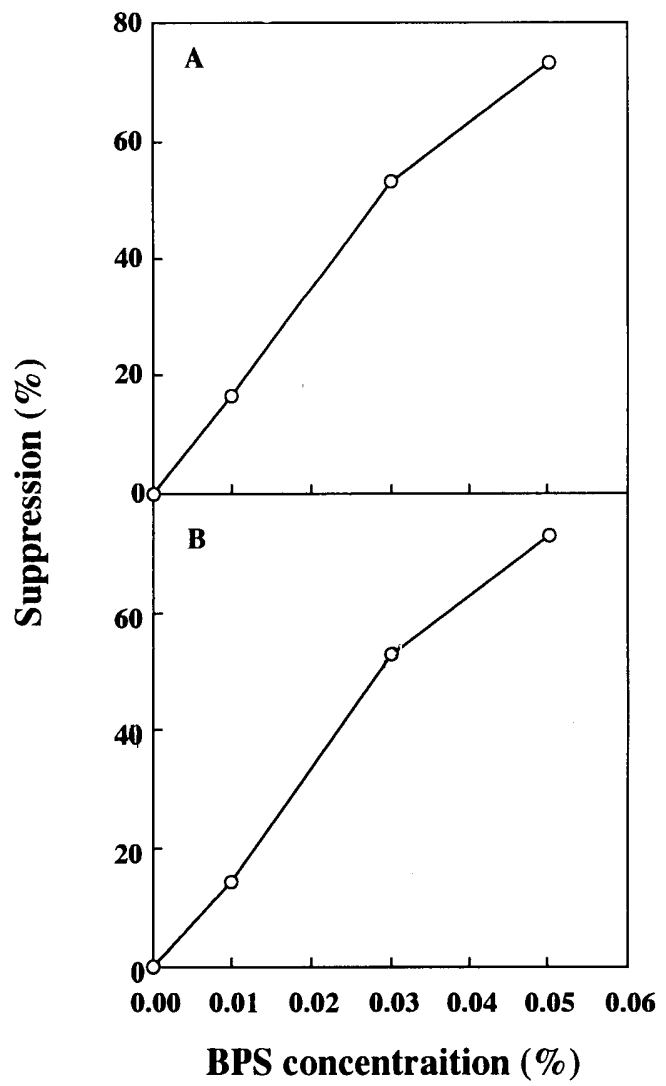

Fig. 1. Effects of BPS concentration on SOS response indused by IQ and MeIQx. Various concentrations of BPS were added to the $u m u$ gene expression system as described in Materials and Methods. IQ (A: $0.3 \mu \mathrm{g} / \mathrm{ml}$ ) and MeIQX (B: $0.03 \mu \mathrm{g} / \mathrm{ml}$ ) were used as mutagens. Each value is expressed as the average of two experiments with triplicate assays. 
Suppressing effect of polysaccharides on SOS response The suppressing effects of BPS on the SOS response of $S$. typhimurium induced by various kinds of mutagens were compared with those of commercial polysaccharide, e.g., carboxymethyl cellulose (CMC), guar gum, and xanthan gum. The concentration of the polysaccharide was $0.05 \%$ in the reaction mixture. As shown in Table 1, BPS suppressed the SOS response which was induced by IQ and MeIQx strongly, and by Trp-P-2 slightly. Guar gum suppressed IQ and MeIQx, but CMC and xanthan gum showed less suppressing effect.

The effect of the molecular size of the polysaccharides on the suppression of SOS response was investigated. A lowmolecule polysaccharide (M.W.: $1-2 \times 10^{6}<$ ) was prepared by heating native polysaccharide (M.W.: $2 \times 10^{7}$ ) under acidic conditions (see Materials and Methods), and it was tested for the suppression of the SOS response. The suppression by lowmolecule polysaccharide of the SOS response induced by IQ, MeIQx and Trp-P-2 was $11.9 \%, 11.1 \%$ and $0.1 \%$, respectively. The low-molecule polysaccharide had less suppressing effect than the native polysaccharide as shown in Table 1.

The effect of BPS concentration on the suppression of the SOS response induced by IQ and MeIQx is shown in Fig.1. The suppressing effect of BPS increased linearly with the concentration of BPS.

The mechanism of suppression on the SOS response of BPS previously shown is considered as follows: It is supposed that BPS acts as a des-mutagen because BPS cannot flow into the cell because of its high molecular size (M.W.: $2 \times 10^{7}<$ ). Concerning the cell fractions of various microorganisms, Zhang and Ohta (1993) reported that peptidoglycan and glucan isolated from the cell wall showed a high binding ablilty to Trp-P-1. It is supposed that the suppressing effect of polysaccharide on the SOS response may be due to the adsorption of mutagens to the polysaccharide molecule to prevent them from flowing into the cell, the same as the cell wall fraction. Because the suppression of BPS on the SOS response induced by indirect mutagens (IQ, MeIQx) activated by the S9mix was high compared with the direct mutagens, the inactivation of the metabolizing enzyme in the S9mix may also be one of the reasons for suppression on the SOS response. This mechanism of suspression on the SOS response is under investigation. In Table 1, it is based on the reactivity with mutagen or enzyme that the level of suppression differs from polysaccharides. The suppression on the SOS response of BPS was lost by lowering of molecular size, which shows that a high molecular size of polysaccharide is necessary for the adsorption of mutagen or the inactivation of the enzyme to exhibit a suppressing effect on the SOS response. The suppressing effect of BPS increased with the concentration of BPS, indicating that the suppression may depend on increasing the adsorption rate of the mutagens or enzyme to the polysaccharide.

Many studies on the antimutagenisity of fiber from crops and vegetables are reported (see Introduction). However, the antimutagenisity of bacterial polysaccharide has not been reported, except for one report (Frolov et al., 1989). We have attempted to study the various functions of the bacterial polysaccharide produced by $B$. circulans for the application to processed foodstuffs. The bacterial polysaccharide can be stably produced and has characteristic properties in rheology and physiological activity different from natural gums. They are also less harmful to environmental pollution than synthetic polymers because they are biodegraded in the natural world. The result of this study may add a new physiological value to bacterial polysaccharide from $B$. circulans for use as a food additive. However, for the application to food it is necessary to confirm the safety of bacterial polysaccharide.

Acknowledgments We acknowledge Dr. Yoshimistu Oda, Osaka Prefectural Institute of Public Health, Osaka, and Dr. Rieko Nakata, Department of Food Science and Nutrition, Nara Women's University, for helpful advice, and thank Miss Mio Koike and Miss Miwa Hashimoto, Department of Food Science and Nutrition, Nara Women's University, for their assistance.

\section{References}

Barbolt, T.A. and Abraham, R. (1978). The effect of bran on dimethylhydrazine-induced colon carcinogenesis in the rat. Proc. Soc. Exp. Biol. Med., 157, 656-659.

Barnes, W.S., Maiello, J. and Weisburger, J.H. (1983). In vitro binding of the food mutagen 2-amino-3-methylimicazo[4,5-f] quinoline to dietary fibers. J. Natl. Cancer Inst., 70, 757-760.

Burkitt, D.P. (1971). Epidemiology of cancer of the colon and rectum. Cancer, 28, 3-13.

Edenharder, R., Leopold Ch. and Kries, M. (1995). Modifying actions of solvent extracts from fruit and vegetable residues on 2-amino-3methylimidazo[4,5-f]quinoline (IQ) and 2-amino-3,4-dimethylimidazo[4,5-f] quinoxaline (MeIQx) induced mutagenesis in Salmonella typhimurium TA98. Mutat. Res., 342, 303-318.

Frolov, A., Varbanets, L., Antonenko, S., Rybalko, S. and Zakharova, I. (1989). Polysaccharide - a stimulant of DNA reparative synthesis. Mikrobiol. Zh., 51, 98-99.

Hayatsu, H., Arimoto, S. and Negishi, T. (1988). Dietary inhibitors of mutagenesis and carcinogenesis. Mutat. Res., 202, 429-446.

Isobe, Y., Toyama, Y., Minamori. M., Yokoigawa, K., Endo, K. Kawai, F. and Kawai, H. (1996). Comparison of physicochemical properties of a novel polysaccharide produced by Bacillus circulans with commercial polysaccharide. Nippon Shokuhin Kagaku Kogaku Kaishi, 43, 634-641

Kada, T., Kato, M., Aikawa, K. and Kiriyama, S. (1984). Adsorption of pyrolysate mutagens by vegetable fibers. Mutat. Res., 141, 149151.

Kawai, H., Isobe, Y., Horibe, M., Tokuda, J., Tokuno, I., Endo, K. and Kawai, F. (1992). Production of a novel extracellular polysaccharide by Bacillus strain isolated from soil. Biosci. Biotech. Biochem. 56, 853-857.

Miller, J.H. (1972). "Experiments in Molecular Genetics," Cold Spring Harbor Laboratory, Cold Spring Harbor, NY, pp. 352-355.

Morita, K., Hara, M. and Kada, T. (1978). Studies on natural desmutagens: Screening for vegetable and fruit factors active in inactivation of mutagenic pyrolysis products from amino acid Agric. Biol. Chem., 42, 1235-1238.

Oda, Y., Nakamura, S., Oki, I., Kato, T. and Shinagawa, H. (1985). Evaluation of the new system (umu-test) for the detection of environmental mutagens and carcinogens. Mutat. Res., 147, 219229.

Okabe, Y., Simnoto, H., Tsusida, T. and Tokuda, S. (1996). Antimutagenicity of the extracts from four root crops on the Trp-p-2induced mutagenicity to Salmonella typhimurium TA98. Nippon Shokuhin Kagaku Kogaku Kaishi, 43, 36-39 (in Japanese).

Takeuchi, M., Hara, M., Inoue, T. and Kada, T. (1988). Adsorption of mutagens by refined corn bran. Mutat. Res., 204, 263-267.

Zhang, X.B. and Ohta, Y. (1993). Antimutagenicity of cell fractions of microorganisms on potent mutagenic pyrolysate. Mutat. Res., 298, $247-253$. 